\title{
Stimulation of Soil Microbiological Activity by Clinoptilolite: The Effect on Plant Growth
}

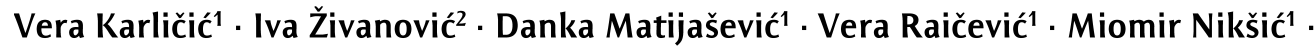 \\ Vladislav Rac ${ }^{1}$ Aleksandar Simić ${ }^{1 *}$
}

${ }^{1}$ University of Belgrade, Faculty of Agriculture, Nemanjina 6, 11080 Belgrade - Zemun, Serbia

${ }^{2}$ Norwegian University of Life Sciences, Department of Plant and Environmental Sciences, Oslo, Norway

\begin{abstract}
Summary: Zeolites can mitigate ammonium losses to the environment by taking up the ions from sources such as farmyard manure and ammonium-bearing fertilizers. This ability can improve nitrogen fertilizing practice given that ammonium ions loaded onto zeolite are available for plant uptake. The main goal of this study was to assess the influence of zeolite (clinoptilolite) and ammonia-loaded clinoptilolite on growth and yield of red clover (Trifolium pratense L.), as well as their influence on the microbial dynamics in soil. Plants sown in pots were cut four times, and dry matter yield (DM) of each harvest was weighed. The number of culturable bacteria, moulds, ammonifiers, Azotobacter sp. and actinomycetes was determined at the beginning of the experiment, and after each harvest. Two control treatments (soil without fertilizer and soil supplemented with mineral fertilizer - CAN) were included in the study. The application of ammonia-loaded clinoptilolite positively and significantly affected the microbial activity and provided higher yields (from $4.9 \mathrm{~g} /$ pot in ammonia-loaded clinoptilolite treatment to $4.3 \mathrm{~g} / \mathrm{pot}$ in soil with zeolite treatment). Our results suggest that the addition of clinoptilolite to organic fertilizers (manure, composts) could be recommended. The increase of microbial communities' abundances and their activity represented the key benefit from clinoptilolite application.

Key words: clinoptilolite, microbiological activity, red clover, soils, zeolites
\end{abstract}

\section{Introduction}

Worldwide agricultural practices are facing two challenges. There is an increasing need for high quality and quantity yields. On the other side environmental concerns are becoming main limiting factor for sustainable agriculture. In an effort to reconcile need for high yields and minimization of environmental impact, modern agriculture has to implement environmentally sustainable approaches. An eco-friendly material, such as zeolite, would help mitigate the impact of agricultural production by decreasing the loss of ammonium to the environment (Nguyen and Tanner, 1998), while it could have a beneficial effect on the yield given that the ammonium ions bound on zeolite are available for plant uptake (Ando et al., 1996). Soil microorganisms as a crucial factor in plant nutrition play significant role in sustainable approaches (Glick, 2012), so revealing interactions between plants, soil, zeolite and microorganisms is

Corresponding author:

alsimic@agrif.bg.ac.rs

Acknowledgements: This investigation was financed by the Norwegian Programme in Higher Education, Research and Development (Project: The use of natural zeolite (clinoptilolite) for the treatment of farm slurry and as a fertilizer carrier) and the Ministry of Education and Science of the Republic of Serbia, Grant No. TR 31080. essential for assessment of the beneficial effect of the zeolite application in agricultural production.

Zeolites are hydrated aluminosilicates characterized by complex three dimensional crystalline structures. Previous study has shown that due to their high cation exchange capacity zeolites can improve ammonium and nitrate ions retention in the soil (Palanivell et al., 2015). Zeolites are known to include $\mathrm{NH}_{4}{ }^{+}$in their structure in zeolite-fertilizer mixtures (farmyard manure, composts, or ammonium-bearing fertilizers), implying a reduction of nitrogen losses to the environment (Bernardi et al., 2016). Gholamhoseini et al. (2013) reported that most quantitative and qualitative sunflower traits improved when $14-21 \%$ of zeolite was added to the fresh manure compared to the integrated urea + composted manure treatment. Their study on a poor sandy soil revealed that the combined application of zeolite with organic and mineral $\mathrm{N}$ fertilizers enhanced sunflower seed yield, while the applied zeolite also prevented leaching of excess $\mathrm{N}$. It has been reported that the application of zeolite leads towards a higher availability of not only nitrogen, but also phosphorus, calcium, and magnesium (Abdi et al., 2006). Zeolites have a capability to bind humic acid through the action of the surface cations (Ramesh \& Reddy, 2011), and they also can hold water within its pores. Water can form a layer around surface by desorption generating friendly environment for 
microorganisms (Leggo et al., 2006). Majority of current data on relations between zeolites and soil microflora show a positive effect of these minerals on quantitative composition of soil microorganisms (Andronikashvili et al., 2008; Leggo et al., 2006).

In agricultural practice, zeolites have been used as soil conditioners and for nitrogen fertilizing improvements (Bernardi et al., 2016) for a long time. Their incorporation in soil was found to increase crop yield and promote nutrient use efficiency (Ramesh \& Reddy, 2011). The most abundant zeolite in nature is clinoptilolite (Bernardi et al., 2016) often used as a source of potassium and ammonium ions (Trinchera et al., 2010).

Simić et al. (2013) suggested that plants may show good response on clinoptilolite used as a fertilizer carrier, and that it has a potential to improve cattle farm - manure organic fertilizer system for forage crops. Such method of fertilization is ecologically advantageous since the active compounds and nutrients are washed out into the soil gradually (Malekian et al., 2011).

Herbage legumes are central to most herbage livestock systems, including those of the cool and humid regions of the world, and they are a predominant source of proteins for ruminants. Red clover is cultivated in about 120,000 ha in the Republic of Serbia, and is shown to be highly adaptable to more acidic and shallow soils, especially in mountainous regions (Mandić et al., 2011).

Hejduk \& Knot (2010) showed that red clover increases herbage quality and production with low fertilization requirements in temporary and permanent grasslands. Vasiljević et al. (2010) reported that red clover is mostly present in pure stands on arable land, but as well as in mixtures with grasses and at a limited extent also in permanent swards.

This study aimed to evaluate: a) the effect of clinoptilolite supplement on the growth of red clover, b) the effect of supplementing clinoptilolite enriched with ammonia, c) the effect of both types of clinoptilolite on the soil microbial community.

\section{Material and Method}

Naturally formed zeolite was used for the study (Zlatokop deposit, Vranjska Banja, Serbia) containing $70 \%$ of clinoptilolite (zeolite CLI) $\left(\mathrm{Ca}_{1.6} \mathrm{Mg}_{0.7} \mathrm{~K}_{0.7} \mathrm{Na}_{0.3} \mathrm{Al}_{5.5} \mathrm{Si}_{26} \mathrm{O}_{72} \cdot 23 \mathrm{H}_{2} \mathrm{O}\right)$ with a grain size $0.063-0.1 \mathrm{~mm}$.

\section{Substrate characteristics}

The soil used for the experiment was Planosol (pseudogley) (WRB, 2014) collected from the plow layer $(0-20 \mathrm{~cm})$ of an arable soil located in the vicinity of Šabac (4440’40”N 19³9’05”'E, 123 m a.s.l.), Serbia.

The soil was air-dried, passed through $2 \mathrm{~mm}$ sieve, homogenized and subsequently analyzed in order to make an initial characterization of the soil (Table 1). The $\mathrm{pH}$ value of the soil was determined in distilled water and $0.01 \mathrm{M} \mathrm{CaCl}$ by Orion $\mathrm{pH}$ meter connected to Ross combined $\mathrm{pH}$ electrode. The extraction of elements $(\mathrm{P}, \mathrm{K})$ was done in ammonium lactate (AL) solution, and the extraction performed according to Egner et al. (1960) was followed by measurements on ICP-OES (Perkin-Elmer Optima 5300 DV). For the determination of total carbon and total nitrogen contents the Leco CHN 1000 analyzer was used (Table 1).

Experimental soil belongs to acid soil category with moderate soil organic carbon content, and suboptimal capacity to provide the plant with nitrogen. The soil had lower than optimal phosphorus (Krogstad, 2008) and potassium contents as well.

The textural class of silty clay loam $(21.1 \%$ clay, $71.4 \%$ loam, $7.5 \%$ sand) used in the experiment was determined according to the USDA Soil Survey manual (USDA, 1993).

\section{Soil preparation}

Soil samples collected at the site were pooled and homogenized whereas stones and roots were removed. The soil was $\mathrm{pH}$ was adjusted from 5.73 to $\sim 6.5$ by adding moderate amount of $\mathrm{CaCO}_{3}$. All plant nutrients other than nitrogen were provided as follows, in $\mathrm{mg} \mathrm{kg}^{-1}$ soil: P, 41.5; K, 70.2; Mg, 9.6; Fe, 5.6; Mn, 1.1; Cu, 0.32; Mo, 0.48; B, 0.11; Zn, 0.65. The addition of these nutrients limits their effect on plant growth (Wang, 2016).

\section{Preparation of ammonia-loaded zeolite CLI}

The ammonia-loaded zeolite CLI was prepared using wet ion-exchange procedure. First, $20 \mathrm{~g}$ of clinoptilolite was added to $1 \mathrm{~L}$ of $350 \mathrm{mg} \mathrm{L}^{-1}$ solution of $\mathrm{NH}_{4} \mathrm{Cl}$ and the suspension was stirred using a magnetic stirrer for $24 \mathrm{~h}$ at room temperature. The nitrogen containing zeolite CLI was then separated from the solution by filtration and dried at room temperature for $48 \mathrm{~h}$. Applied nitrogen enriched zeolite CLI rate of $10 \mathrm{~g} \mathrm{~kg}^{-1}$ of soil was equivalent to nitrogen fertilization rate of $100 \mathrm{~kg} \mathrm{ha}^{-1}$ (Milovanović et al., 2013).

Table 1. Chemical properties of the soil

\begin{tabular}{|c|c|c|c|c|c|c|}
\hline \multirow{2}{*}{ Soil type } & \multicolumn{2}{|c|}{$\mathrm{pH}$} & \multirow{2}{*}{$\begin{array}{c}\mathrm{AL}_{-} \mathrm{P}_{2} \mathrm{O}_{5} \\
\mathrm{mg} \mathrm{kg}^{-1}\end{array}$} & \multirow{2}{*}{$\begin{array}{c}\mathrm{AL}-\mathrm{K}_{2} \mathrm{O} \\
\mathrm{mg} \mathrm{kg}^{-1}\end{array}$} & \multirow{2}{*}{$\begin{array}{c}\text { Total C } \\
\%\end{array}$} & \multirow{2}{*}{$\begin{array}{c}\text { Total N } \\
\%\end{array}$} \\
\hline & in $\mathrm{H}_{2} \mathrm{O}$ & in $\mathrm{CaCl}_{2}$ & & & & \\
\hline Planosol & 5.73 & 5.07 & 19.8 & 115.1 & 1.37 & 0.16 \\
\hline
\end{tabular}




\section{Experimental design}

A total of 4 treatments with four replicates/pots was investigated using randomized experimental design. The treatments were as follows: a) soil without fertilizer (control); b) soil with zeolite CLI $\left(10 \mathrm{~g} \mathrm{~kg}^{-1}\right)$; c) soil with ammonia-loaded zeolite CLI (10 $\left.\mathrm{g} \mathrm{kg}^{-1}\right)$; d) nitrogen application through mineral fertilizer Calcium ammonium nitrate $\left(100 \mathrm{~kg} \mathrm{ha}{ }^{-1} \mathrm{~N}, 27 \%\right.$ nitrogen content, $41.7 \mathrm{mg} \mathrm{N} \mathrm{kg}^{-1}$ soil). The experiment was conducted in a growth chamber during 2014 using plastic pots filled with approximately $2 \mathrm{~kg}$ of air-dried soil as a growth medium.

Red clover (Trifolium pratense L.) seeds cv. Una (50 seeds) were sown to each pot and placed in a growth chamber. During the experimental period, the crop was harvested four times with approximately 25 days between two cuts. After plants attained a height of approximately $10 \mathrm{~cm}$ they were cut at a height of $3 \mathrm{~cm}$ from soil surface. The cutting was repeated three more times. The plant material was dried at $60{ }^{\circ} \mathrm{C}$ until a constant mass and the dry matter yield was weighed. Optimal plant growth conditions were maintained by regular watering which assured that the soil moisture in the pots was at about $60 \%$ of soil field capacity. Average air temperature in the chamber was $23{ }^{\circ} \mathrm{C}$, and there were 12 hours of irradiance $13000 \mathrm{~lx}$ per day.

Quantification of soil microbial populations and debydrogenase activity

Microbiological analyses were conducted at the beginning of the experiment and after every cut. Serial dilution and plating on selective media was used for the determination of the colony-forming units (CFUs) of culturable bacteria, moulds, ammonifiers, Azotobacter sp. and actinomycetes. Ten grams of each root-zone soil sample was individually dispensed into $90 \mathrm{~mL}$ of $0.1 \%$ $(\mathrm{w} / \mathrm{v})$ sterile solution of sodium chloride. The soil suspensions were agitated at $250 \mathrm{rpm}$ for $20 \mathrm{~min}$. Tenfold dilutions were made in sterile deionized water, and $0.5 \mathrm{~mL}$ aliquots of each soil dilution were spread on the surface of the different substrates in sterile Petri dishes. Plate counts of the culturally viable bacteria were made on 0.1 x Triptonite soy agar, moulds on Rose Bengal agar that was amended with $30 \mathrm{mg}^{-1}$ of streptomycin sulfate, ammonifiers on Nutrient agar. The number of Azotobacter CFUs was estimated on Fjodorov medium. Actinomycetes were counted on Starch-ammonia agar (Churkina et al., 2012). Three replicates of the inoculated agar plates were incubated at $28{ }^{\circ} \mathrm{C}$ for $72 \mathrm{~h}$ for total number of bacteria and ammonifiers, 10 days for actinomycetes, 5 days for Azotobacter sp. and moulds, after which colonies were counted. Microbiological counts were expressed as $\log \left(\mathrm{cfu} \mathrm{g}^{-1}\right)$. Microbial dehydrogenase activity (DHA) was determined with 2,3,5-triphenyltetrazolium chloride (TTC) and expressed as $\mu \mathrm{g}$ TPF $/ \mathrm{g} / \mathrm{h} \times 10^{-5}$.

\section{Statistical analyses}

Statistical analysis was carried out using the $\mathrm{R}$ (version i386 3.1.1) software package. Differences between the treatments were evaluated with the Tukey's test at $\mathrm{p}<0.05$ level.

\section{Results}

The first results showed that the greatest shoot production was in the soil enriched with ammonialoaded zeolite CLI. This has been continued through the next cuttings, but high variability in DM yield obtained from pots treated with the same treatment diminished the significance of the difference in the last two cuts (Table 2). The application of pure zeolite CLI did not significantly improve the biomass production during the experimental period, and the recorded total dry matter yield was significantly lower compared to total dry matter yield obtained with ammonia-loaded zeolite CLI treatment.

For the ANOVA procedure we considered cutting as one factor (with four levels) and treatment as the other (with four levels). As expected, the difference in $\mathrm{DM}$ yield between the cuts was significant with $\mathrm{p}$-value of $2.2 \cdot 10^{-16}$. This can be explained by difference in plant development. It is possible to say with $99 \%$ certainty that there is an effect of the treatment ( $p$-value $=0.006$ ), but there is also a significant effect of the interaction ( $\mathrm{p}$ value $=0.01)$. In the $1^{\text {st }}$ cut the lowest $\mathrm{DM}$ yield was obtained in pots treated with mineral fertilizer, while the lowest DM yield in the $2^{\text {nd }}$ cut was in pots treated with

Table 2. Mean dry matter yield (DM) after red clover cuttings (in grams per pot);

\begin{tabular}{lccccc}
\hline \multirow{2}{*}{ Treatment } & \multicolumn{2}{c}{ Cuts } & \multicolumn{2}{c}{ Total } \\
\hline Control & I & II & III & IV & $4.422^{\mathrm{AB}}$ \\
$\mathrm{Z}_{\mathrm{CLI}}$ & $0.971^{\mathrm{ab}}$ & $1.514^{\mathrm{ab}}$ & $0.710^{\mathrm{a}}$ & $1.226^{\mathrm{a}}$ & $4.305^{\mathrm{B}}$ \\
$\mathrm{Z}_{\mathrm{CLI}}+\mathrm{NH}_{4}$ & $0.966^{\mathrm{ab}}$ & $1.298^{\mathrm{b}}$ & $0.672^{\mathrm{a}}$ & $1.369^{\mathrm{a}}$ & $4.923^{\mathrm{A}}$ \\
$\mathrm{CAN}$ & $1.130^{\mathrm{a}}$ & $1.646^{\mathrm{a}}$ & $0.754^{\mathrm{a}}$ & $1.394^{\mathrm{a}}$ & $4.397^{\mathrm{AB}}$ \\
\hline
\end{tabular}

Z $\mathrm{Z}_{\mathrm{CLI}}$ zeolite CLI; $\mathrm{Z}_{\mathrm{CLI}}+\mathrm{NH}_{4}$ - ammonia-loaded zeolite CLI; CAN - Calcium ammonium nitrate; I-the first red clover cut; II-the second red clover cut; III-the third red clover cut; IV-the fourth red clover cut. Means in columns followed by the same letter are not significantly different according to Tukey's post-hoc test at $\mathrm{p}<0.05$. 
zeolite CLI. One-way ANOVA procedure for the effect of treatment (as a single factor with four levels) on total DM yield has shown that the treatment effect was significant with $95 \%$ certainty (p-value 0.02 ).

Microbial analyses were conducted after every cut to reveal any treatments' influence on changes and dynamics through time. During three months experimental period, number of total bacteria, moulds, ammonifiers, Azotobacter sp., and actinomycetes were determined and microbial analyses showed an increase of all monitored groups (Figure 1). The original number of bacteria and moulds was obviously lower at the start of the experiment than during later sampling. At the end of the experiment the largest rise of total bacteria population was noted in treatments amended with zeolite CLI, especially, in substrate enriched with ammonia-loaded zeolite CLI. One-way ANOVA

a

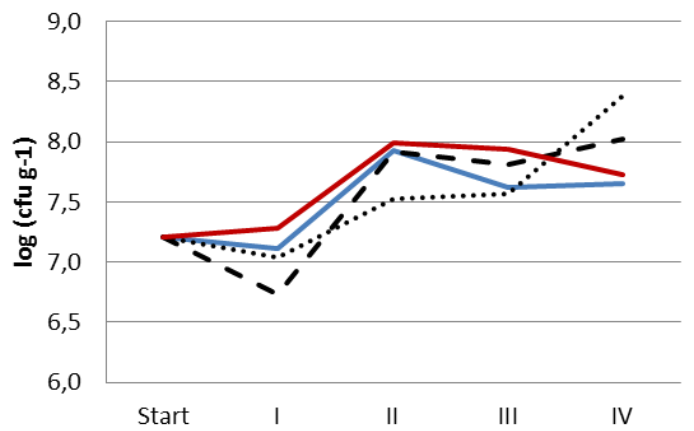

C

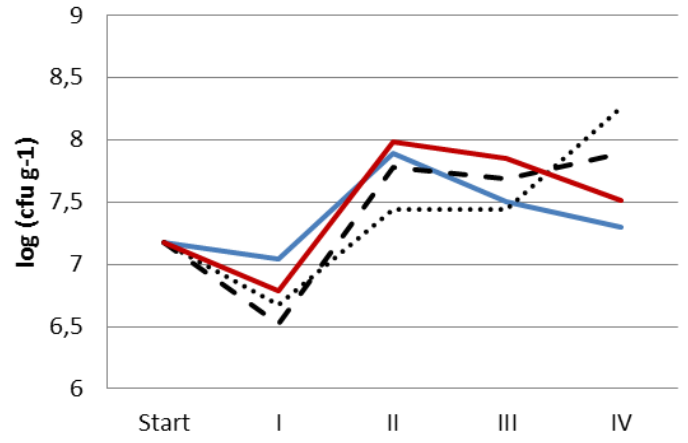

e

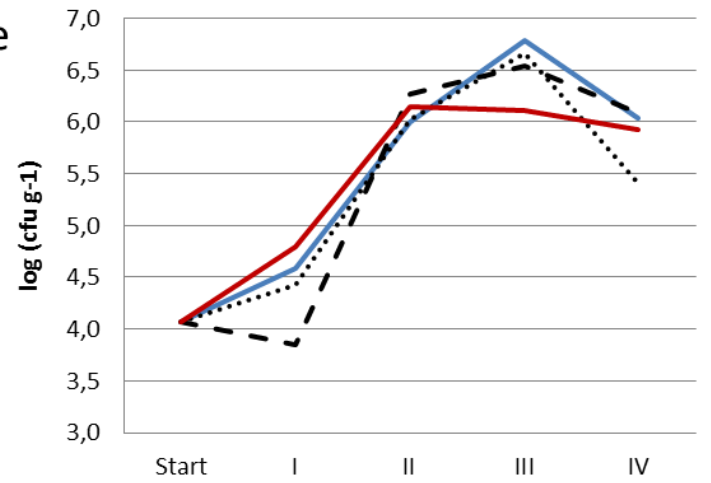

procedure for the effect of treatment on number of bacteria showed that those treatments were significantly more populated than others $(\mathrm{p}$-value $<0.001)$ at the end of the experiment. Treatment with ammonia-loaded zeolite CLI, also, showed higher growth rate of moulds compared to other treatments. We can claim with $99 \%$ certainty that its presence was significantly greater. The similar observations were in case of ammonifiers, both treatments with zeolite CLI showed higher growth rate compared to control and treatment with mineral fertilizer.

The amount of DHA was measured at the beginning and the end of the experiment (Table 3). Obtained results confirmed changes in soil microbial communities in all treatments. The increase of enzymatic activity was observed in all treatments compared to initial state. The higher activity was noted in treatment with mineral
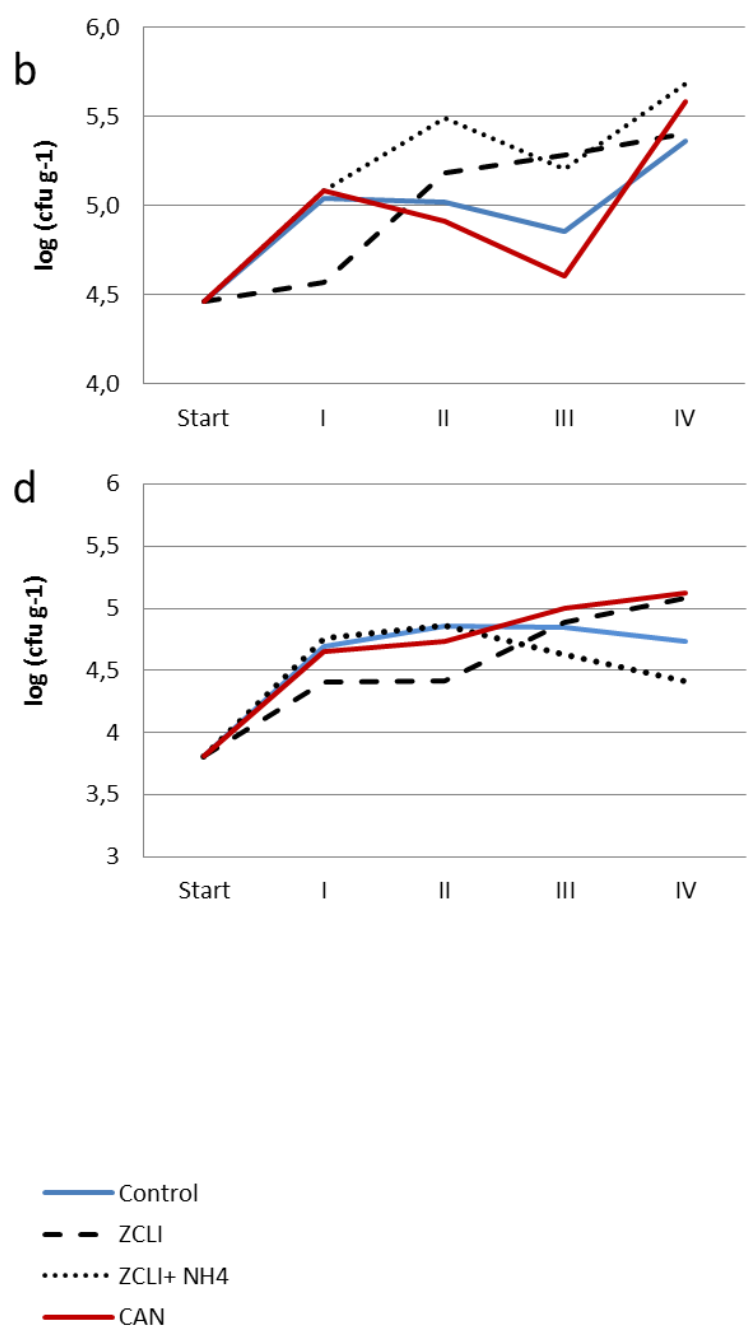

Figure 1. The influence of the fertilizer treatments on the number of soil bacteria during red clover vegetation a) total bacteria; b) moulds; c) Ammonifiers; d) Azotobacter sp.; e) Actinomycetes; $\mathrm{Z}_{\mathrm{CLI}}-$ zeolite CLI; $\mathrm{Z}_{\mathrm{CLI}}+\mathrm{NH}_{4}-$ ammonia-loaded zeolite CLI; CAN - Calcium ammonium nitrate; I-the first red clover cut; II-the second red clover cut; III-the third red clover cut; IV-the fourth red clover cut. Means in columns followed by the same letter are not significantly different according to Tukey's post-hoc test at $\mathrm{p}<0.05$. 
fertilizer. According to Tukey post-hoc test, treatments with zeolite CLI showed significantly higher amount of DHA compared to control ( $\mathrm{p}$-value $<0.001)$.

Table 3. The fertilizer treatments influence on dehydrogenase activity (TPF $\mu \mathrm{g} / \mathrm{g} / \mathrm{h} \times 10^{-5}$ );

\begin{tabular}{llll}
\hline \multirow{4}{*}{ DHA } & Treatment & Start & Finish \\
\cline { 2 - 4 } & Control & & $4.76^{\mathrm{d}}$ \\
& Z $_{\text {CLI }}$ & & $5.88^{\mathrm{c}}$ \\
& $\mathrm{Z}_{\text {CLI }}+\mathrm{NH}_{4}$ & 3.98 & $6.13^{\mathrm{b}}$ \\
& CAN & & $7.27 \mathrm{a}$ \\
\hline
\end{tabular}

Z $\mathrm{CLI}_{-}$zeolite CLI; $\mathrm{Z}_{\mathrm{CLI}}+\mathrm{NH}_{4}$ - ammonia-loaded zeolite CLI; CAN Calcium ammonium nitrate; I-the first red clover cut; II-the second red clover cut; III-the third red clover cut; IV-the fourth red clover cut. Means in columns followed by the same letter are not significantly different according to Tukey's post-hoc test at $\mathrm{p}<0.05$.

\section{Discussion}

It is well known that zeolites are capable of taking up nutrients, especially nitrogen, from both organic and mineral fertilizers, and preventing their loss through running off, leaching, and volatilization (Ando et al., 1996; Zaman \&Nguyen, 2010). The idea was to apply ammonia-loaded zeolite CLI in the amount which represents equivalent to those mixed with farmyard manure or composts, and to test its effects on red clover yields and abundance of several groups of microorganisms. The obtained results showed that nitrogen enrichment of zeolite CLI through addition of ammonia had positive effect on red clover yield. This result implies that zeolite CLI mixed with organic fertilizer (manure) could have favorable effect as well, which is in accordance with our previous work (Simić et al., 2013) where 10 wt. \% zeolite CLI added to fresh cattle manure increased retention of realized ammonia by $90 \%$ in comparison to the system without zeolite CLI. Results similar to ours were reported by Malekian et al. (2011) for corn grown on soil amended with clinoptilolite and nitrogen fertilizer where the application of zeolite CLI increased the ratio of $\mathrm{N}$ uptake to applied $\mathrm{N}$ fertilizer and supported plant growth. Even though some synthetic zeolites mixed with normal fertilizers may enhance the growth and yield of the crops, as demonstrated for Prunus persica and Vitis vitifera by Burriesci \& Valente (1984), Malekian et al. (2011) suggested that plants may have a better response if a natural zeolite, such as clinoptilolite, is used as a fertilizer carrier. The advantage of applying natural zeolite to farmyard manure is not just limited on its capability to take up ammonium ions. Natural zeolites can also influence bioavailability of other plant nutrients and there are some indications that it contributes to phosphorus release in the first $24 \mathrm{~h}$ for about $60 \%$, while zeolite modified with $\mathrm{NH}_{4}{ }^{+}$increases release of phosphorus for additional $150 \%$ when added to the rock phosphate (Lopičić et al., 2013). Zeolites effect on the dry matter yield might also be attributed to its capability to maintain adequate water supply, as well as to supplement micronutrients (Burriesci \& Valente, 1984).

Literature data claims that microbial populations could respond to zeolite amendment in different ways. Mühlbachová \& Šimon (2003) noted that zeolite amended soil slightly, but not significantly, decreases its microbial biomass. On the contrary, several authors claimed that quantity of microorganisms can be increased in organozeolitic amended soils (Leggo et al., 2006; Ramesh \& Reddy, 2011). Microbiological analyses performed in this work revealed changes in microbial biomass during the experimental period in all treatments, but those changes were more noticeable in amended treatments compared to control. Increasing the number of microorganisms included in nitrogen cycling (ammonifiers, Azotobacter sp.) is important as a biological way of enriching soil with nitrogen in plant available form. This, consequently, raises soil fertility. In zeolite CLI treatment number of Azotobacter sp. grew constantly, which is also observed by Andronikashvili et al. (2008) and Leggo et al. (2006). After the second cutting, presence of this group of microorganisms decline in treatment with ammonia-loaded zeolite CLI. The results obtained in this treatment indicate that in some point of the experiment unfavorable conditions occurred for free diazotrophs. It is possible that amount of ammonia added as a part of the treatment and produced by increasing number of ammonifiers was surplus. High presence of ammonia may cause inhibition of nitrogenase activity and lower down nitrogen fixation (Rodionov et al., 1986) assumingly that happened here. The rise in number of actinomycetes was constant in all treatments up to the third cutting. Andronikashvili et al. (2008) reported that clinoptilolite-containing tuffs in red and podzolic soils rise number of actionomycetes. After the third cutting number of these group of bacteria declined in all treatments and that can be the indicator of nutrient shortage and soil depletion.

Monitored groups of microorganisms were under constant influence of red clover seedlings. Plant roots stimulate the growth of indigenous soil microbiota by secreting a number of compounds, grouped under the term of mucigel (Garg, 2007). Those compounds are indispensable for communication in rhizosphere. Emergence and growth of plant acts stimulatory on soil microbes, root system and its exudation of carbon compounds provide almost all the nutrient sources lacking in soil (Hartmann et al., 2008). This is the rhizospheric effect which causes changes in microbial communities. On the other hand, rhizospheric effect may be influenced by zeolite application, too. Trinchera et al. (2010) reported positive effects of clinoptilolite amendment on root system growth, complexity and production of mucigel and exudates. Comparison between granular $(1-3 \mathrm{~mm})$ and micronized $(<30 \mu \mathrm{m})$ particles of zeolites emphasize micronized particles as 
more effective in its interaction with root surface. In our work, particles had diameters less than $100 \mu \mathrm{m}$, and its size enable its positive effects on root apparatus and mucigel secretion which consequently leads to higher presence of microorganisms.

All the factors that affect nutrient cycling in soil have crucial impact on plant production. The processes engaged in nutrient cycling are controlled by soil enzymes and microorganisms (Järvan et al., 2014). Dehydrogenases are one of the most important enzymes in soil, indicating total soil microbial activity ( $\mathrm{Gu}$ et al., 2009), soil fertility (Wolińska \& Stepniewska, 2012) and oxidative activity of soil microorganisms. Dehydrogenase is affected by the same factors that influence abundance of microorganisms (Järvan et al., 2014; Wolińska \& Stepniewska, 2012). Bagherifam et al. (2014) recorded that zeolites increased the activity of dehydrogenase in arsenic contaminated soil. Comparison of DHA in control and other treatments confirm that presence of plant is not the only factor that affects microbial communities and that the influence of treatments is questionless.

Obtained data show that application of ammonialoaded zeolite CLI provides higher yields and is significantly more efficient than application of zeolite CLI. Data of biomass production support our thesis that ammonia loaded zeolite CLI has beneficial effect on plant growth. Microbiological analyses revealed that presence of ammonia charged zeolite CLI positively affected microbial abundance. This treatment caused the largest rise of total bacteria, moulds and ammonifiers population. The key benefit that this treatment provides is acceleration of microbiological activity which is an important factor in crop productivity. Consequently, enhancement of microbial proliferation and activity raises soil fertility.

\section{Conclusions}

Numerous studies carried out worldwide show that natural zeolites have a place in sustainable agriculture. In the presented study ammonia-loaded zeolite CLI proved to be more effective then parent zeolite CLI in terms of biomass production. The key benefit that zeolite CLI, applied on both forms, provided in this work is the increase of microbial activity. Soil microorganisms are crucial factors in plant nutrition and development. The enhancement of microbial proliferation and their enzymatic activity represents a solid base for an increase in agricultural output and a decrease of mineral fertilizer application.

\section{References}

Abdi, G., Khosh-Khui, M., \& Eshghi, S. (2006). Effects of natural zeolite on growth and flowering of strawberry (Fragaria x ananassa Duch.). International Journal of Agricultural Research, 1, 384-389.
Ando, H., Mihara, C., Kekuda, K., \& Wada, G. (1996). The fate of ammonium nitrogen applied to flooded rice as affected by zeolite addition. Soil Science and Plant Nutrition, 42, 531-538.

Andronikashvili, T., Urushadze, T., Eprikashvili, L., Gamisonia, M., \& Nakaidze, E. (2008). Towards the Biological Activity of the Natural Zeolite - Clinoptilolite - Containing Tuff. Bulletin of the Georgian National Academy of Sciences, 2, 99-107.

Bagherifam, S., Lakzian, A., Fotovat, A., Khorasani, R., Akbarzadeh, S., \& Motadaien, A. (2014). Immobilization of arsenic in a calcareous soil using an iron-, manganese- and aluminium-modified zeolite. Journal of Environmental Science and Technology, 16, 39-54.

Bernardi, A.C.C., Polidoro, J.C., Monte, M.B.M., Pereira, E.I., Oliveira C.R., \& Ramesh, K. (2016). Enhancing Nutrient Use Efficiency Using Zeolites Minerals - A Review. Advances in Chemical Engineering and Science, 6, 295-304.

Burriesci, N., \& Valente, S. (1984). Studies on zeolites in agriculture. Effect on crop growth of Prunuspersica and Vitis vinifera. Zeolites, 4, 373-376.

Churkina, G., Kunanbayev, K., \& Akhmetova, G. (2012). The taxonomic composition of soil microorganisms in the ecosystems of southern chernozems of Northern Kazakhstan. ATI - Applied Technologies \& Innovations, 8, 13-19.

Egner, H., Riehm, H., \& Domingo, W.R. (1960). Untersuchungen über die chemische bodenanalyse als grundlage für die beurteilung des nährstoff-zustandes der böden: II. chemische extractionsmethoden zur phosphor und kaliumbestimmung. Kungliga Lantbrukshögskolans Annaler, 26, 199-215.

Garg, N. (2007). Symbiotic nitrogen fixation in legume nodules: process and signaling. A review. Agronomy for Sustainable Development, 27, 5968.

Gholamhoseini, M., Ghalavand, A., Khodaei-Joghan, A., Dolatabadian, A., Zakikhani, H., \& Farmanbar, E. (2013). Zeolite-amended cattle manure effects on sunflower yield, seed quality, water use efficiency and nutrient leaching. Soil and Tillage Research, 126, 193-202.

Glick, B.R. (2012). Plant Growth-Promoting Bacteria: Mechanisms and Applications. Hindawi Publishing Corporation Scientifica, 2012, 1-15.

Gu, Y., Wag, P., \& Kong, C. (2009). Urease, Invertase, Dehydrogenase and Polyphenoloxidase Activities In Paddy Soils Influenced By Allelophatic Rice variety. European Journal of Soil Biology, 45, 436-441.

Hartmann, A., Schmid, M., van Tuinen, D., \& Berg, G. (2008). Plantdriven selection of microbes. Plant and Soil, 321, 235-257.

Hejduk, S., \& Knot, P. (2010). Effect of provenance and ploidity of red clover varieties on productivity, persistence and growth pattern in mixture with grasses. Plant, Soil and Environment, 56, 111-119.

WRB (2014). World Reference Base for Soil Resources - International soil classification system for naming soils and creating legends for soil maps. Rome, Italy, Food and Agriculture Organization of the United Nations. http://www.fao.org/3/a-i3794e.pdf.

Järvan, M., Edesi, L., Adamson A., \& Võsa, T. (2014). Soil microbial communities and dehydrogenase activity depending on farming systems. Plant, Soil and Environment 60, 459-463.

Krogstad, T., Øgaard, A. F., and Kristoffersen, A. Ø. (2008). New Recommendations for Grass and Cereals in Norwegian Agriculture. NJF Report 4, 42-46.

Leggo, P.J., Ledesert, B., \& Christie, G. (2006). The role of clinoptilolite in organo-zeolitic-soil systems used for phytoremediation. Science of the Total Environment, 363, 1-10.

Lopičić, Z., Mihajlović, M., Stojanović, M., Petrović, M., Milojković, J., Lačnjevac, Č., \& Radulović, D. (2013). $\mathrm{NH}_{4}{ }^{+}$-zeolite/raw phosphate composite as a natural fertilizer and soil remediationa amendment. The 1 st International Congress on Soil Science and XIII National Congress in Soil Science (pp. 163-174). Belgrade, Serbia,

Malekian, R., Abedi-Koupai, P., Eslamian, S.S., Mousavi, S.F., Abbaspour, K.C., \& Afyuni, M. (2011). Ion-exchange process for ammonium removal and release using natural Iranian zeolite. Applied Clay Science, 51, 323-329.

Mandić, V., Tomić, Z., Krnjaja, V., Bijelić, Z., Žujović, M., Simić, A., \& Prodanović, S. (2011). Effect of acid stress on germination and early seedling growth of red clover. Biotechnology in Animal Husbandry, 27, 1295-1303. 
Milovanović J., Simić A., Rakić V., Grbić Alibegović S., Krogstad T., Rajić N. (2013): Zeolite as a binding agent for ammonia ions and as a soil additive. Part I: Ammonia adsorption by the zeolite. Proceedings of the 5th Serbian-Croatian-Slovenian Symposium on Zeolites (pp. 88-91). Zlatibor.

Mühlbachová, G., \& Šimon, T. (2003). Effects of zeolite amendment on microbial biomass and respiratory activity in heavy metal contaminated soils. Plant Soil and Environment, 49, 536-541.

Ramesh, K., \& Reddy, D.D. (2011). Chapter four - zeolites and their potential uses in agriculture. Advances in Agronomy, 113, 219-241.

Nguyen, M.L. \& Tanner, C.C. (1998). Ammonium removal from wastewaters using natural New Zealand zeolites. New Zealand Journal of Agricultural Research, 41, 427-446.

Palanivell, P., Ahmed O.H., Susilawati, K., \& Majid, N.M. (2015). Mitigating ammonia volatilization from urea in waterlogged condition using clinoptilolite zeolite. International Journal of Agriculture and Biology, 17, 149-155.

Rodionov, Y.V., Lebedeva, N.V., \& Kondratieva, E.N. (1986). Ammonia inhibition of nitrogenase activity in purple and green bacteria. Archives of Microbiology, 143, 345-347.

Simić, A., Milovanović, J., Alibegović-Grbić, S., Raičević, S., Rakić, V., Krogstad, T., \& Rajić, N. (2013). Zeolite as a binding agent for ammonia ions and as a soil additive. II: Effect on grass growth and quality. 5th Serbian-Croatian-Slovenian Symposium on Zeolites (pp. 96-99). Zlatibor.

Trinchera, A., Rivera, C.M., Rinaldi, S., Salerno, A., Rea, E., \& Sequi, P. (2010). Granular Size Effect of Clinoptilolite on Maize Seedlings Growth. The Open Agriculture Journal, 4, 23-30.

USDA (1993). Soil survey manual - Soil Conservation Service. U.S. Department of Agriculture Handbook 18.

Vasiljević, S., Mihailović, V., Katić, S., Mikić, A., \& Karagić, Đ. (2010). Potential for yield in red clover (Trifolium pratense L.) varieties. Field and Vegetable Crops Research, 47, 217-223.

Wang, Y., Krogstad, T., Clarke, J. L., Hallama, M., Ogaard, A. F., EichGreatorex, S., Kandeler, E. \& Clarke, N. (2016). Rhizosphere Organic Anions Play a Minor Role in Improving Crop Species' Ability to Take Up Residual Phosphorus (P) in Agricultural Soils Low in P Availability. Frontiers in Plant Science, 7, 1-14.

Wolińska, A., \& Stępniewska, Z. (2012). Dehydrogenase Activity in the Soil Environment. In: R.A. Canuto (ed.), Dehydrogenases (pp. 183210). CC BY 3.0 license. (C) The Author(s).

Zaman, M., \& Nguyen, M.L. (2010). Effect of lime or zeolite on $\mathrm{N}_{2} \mathrm{O}$ and $\mathrm{N}_{2}$ emissions from a pastoral soil treated with urine or nitrate- $\mathrm{N}$ fertilizer under field conditions. Agriculture, Ecosystems \& Environment, $136,254-261$.

\section{Stimulacija zemljišne mikrobiološke aktivnosti sa klinoptilolitom: uticaj na rast biljke}

\section{Vera Karličić · Iva Živanović · Danka Matijašević · Vera Raičević Miomir Nikšić · Vladislav Rac · Aleksandar Simić}

Sažetak: Zeoliti mogu ublažiti otpuštanje amonijaka u prirodu preko uzimanja jona iz izvora kao što su stajnjak i đubriva bogata amonijakom. Ova sposobnost može unaprediti đubrenje azotom preko zeolitom usvojenih amonijum jona koji bi tako postali dostupni za usvajanje biljkama. Cilj ovih ispitivanja je bio procena uticaja zeolita (klinoptilolita) i zeolita obogaćenog amonijakom na rast i prinos crvene deteline (Trifolium pratense L.), kao i na njihovu ulogu u mikrobiološkoj dinamici zemljišta. Biljke sejane u sudovima su košene četiri puta i meren je prinos suve materije (SM) svakog otkosa. Broj bakterija, plesni, amonifikatora, Azotobacter sp. i aktinomiceta je utvrđen na početku ogleda i nakon svakog košenja. U istraživanja su uključena dva kontrolna tretmana (zemljište bez đubriva i zemljište sa dodatim mineralnim đubrivom - KAN). Primena klinoptilolita obogaćenog sa amonijakom je pozitivno i značajno uticala na mikrobiološku aktivnost i povećala je prinos (od 4,9 g po sudu kod tretmana sa klinoptilolitom obogaćenim amonijakom do 4,3 g po sudu u zemljištu sa zemljištem i zeolitom zajedno). Naša istraživanja sugerišu da se može preporučiti dodavanje klinoptilolita organskim đubrivima (stajnjaku, kompostu). Kjučna dobit od primene klinoptilolita bi se ogledala u povećanju zastupljenosti mikrobioloških zajednica i njihove aktivnosti.

Ključne reči: crvena detelina, klinoptilolit, mikrobiološka aktivnost, zemljište, zeolit 